\title{
Evaluation of Genetic Diversity amongthe Pakistani Wheat (Triticumaestivum L.) Lines through Random Molecular Markers
}

\author{
Ali Zeshan ${ }^{1}$, Muhammad Afzal ${ }^{2 *}$, Salem S. Alghamdi², Karien Kettener ${ }^{3}$, Mubashar Ali ${ }^{5}$, \\ Muhammad Mubushar ${ }^{4}$, Shakeel Ahmad ${ }^{4}$. \\ ${ }^{1}$ Centre of Agricultural Biochemistry and Biotechnology (CABB), University of Agriculture Faisalabad; ${ }^{2}$ Legume \\ research unit, molecular biology lab, department of plant production, King Saud University, Riyadh, Saudi Arabia. \\ ${ }^{3}$ Biotechnology lab, University of Sao Paulo State, Botucatu, Sao Paulo, Brazil; ${ }^{4}$ Department of plant production, \\ King Saud University, Riyadh, Saudi Arabia; ${ }^{5}$ Department of Agronomy, PirMehr Ali Shah Arid Agriculture \\ University Rawalpindi, Pakistan.
}

\begin{abstract}
The presence of geneticdiversity is of great importance in improving wheat traits and developing strategies for optimal conservation of germplasm. Genetic diversity was assessed among common wheat cultivars using RAPD (Random Amplified Polymorphic DNA) markers at the Center of Agriculture, Biochemistry and Biotechnology $(C A B B)$, University of Agriculture, Faisalabad. RAPD primers were used among 14 Pakistani wheat cultivars, to screen the progenies and for the identification of the genes of interest. The polymorphic information content (PIC), was measured as the percentage of polymorphic fragments for all primers. A total of 583 bands(84\% polymorphic) in all 14 wheat cultivars was amplified and discriminated all the wheat genotypes. The number of fragments amplified per primer ranged from 35 to 69 with an average of 48.52 fragments per primer averagely was observed. Population structure analysis anddandrogram showed distinct clustering among different wheat genotypes. Millat11, Punjab-11, PBW-222 generated the maximum level of polymorphism, standing alone in the cluster while others are scatteredin different group.As a result, genetically numerous progenies are known, increasing the quality of sorts collections by broadening the genetic base of wheat cultivars. This study additionally indicates that RAPD markers allow quicker response and provide high throughputprocedure of accessions from a variety assortment to assess genetic diversity among wheat genotypes.
\end{abstract}

Key words: Wheat, RAPD, genetic diversity, PCoA, Cluster analysis

*Authors for correspondence: afzal_uaf@hotmail.com 


\section{INTRODUCTION}

Wheat is used as a staple food, being the most important cereal crop all over the world. Wheat is the basis ofhuman nutrition and is economically important worldwide. Common wheat or bread wheat (Triticumaestivum L.), club wheat ( $T$. compactum L.) and durum wheat (T.turgidum L.) are the most commonly used wheat species. About $3.2 \%$ GDP of Pakistan depends on wheat $\left.{ }^{1}\right]$. Wheat (Triticumaestivum L.) grass belongs to family Poaceae and is grown all over the world. The total cultivated area of wheat is more than 200 million hectares and total wheat production is about 733 million tons per year $\left[{ }^{2}\right]$. Wheat has good nutritional value comprised of $58.2 \%$ starch, having sufficient amount of sugar and fat. Wheat nourishment is superior in protein $11.2 \%, 6.8 \%$ pentosans, $1.7 \%$ ash, and $70 \%$ of cases, and having a higher percentage of carbohydrates than other crops $\left[{ }^{3}\right]$. Wheat production facing serious problems in semi-arid regions in the world due to changing environmental conditions $\left[{ }^{4,} 5\right]$ several pathogenic diseases $\left[{ }^{6}\right]$ and its greater nutritional value $\left[{ }^{7,8}\right]$. The lower wheat yield in Pakistan is the result of limited diversity in the genome, which is used in breeding programs $\left[{ }^{56}\right]$.

Geographically southwestern Asia, asits center of origin and according to earliest historical record wheat was an important cultivated crop in this region. Wild species of Triticum are found in Iraq, Syria, Lebanon, eastern Turkey and northern Israel. In Egypt and Greece, wheat was cultivated in pre-historic times at thecenter of diversity for hexaploid wheat is Hindukush $[9,10]$. Several Pakistani cultivars are stoked in seed banks and are notdifferentiated efficiently to demand for breeders concerned with their work. Therefore, the genetic diversity in wheat cultivars needs to be categorized.Genetic diversity is one of the key factors for the improvement of many crop plants including wheat. Plant breeders rely on the availability of genetic diversity during selection in cultivar development. Genetic diversity can be assessed from pedigree analysis, morphological traits or using molecular markers $\left[{ }^{11}\right]$. However, genetic diversity based on pedigree selection have generally been found inflated and unrealistic $\left[{ }^{12}\right]$. Genetic diversity estimates based on morphological traits, suffers from the drawback that such traits are limited in number and is influenced by the environment $\left[{ }^{13}\right]$.Genetic diversity is more important among all crops for successful production of hybrids and new cultivars. Initially, genetic variations were dependent on pedigree records and co-ancestry $\left[{ }^{14}\right]$. The morphological and agronomic attributes of wheat have been evaluated to measure genetic variation and their close relatives. A large number of field experiments were carried out to evaluate the genetic variance according to different morphological attributes and epigenetic possessions required for gene expression through molecular markers $\left[{ }^{15}\right]$. So, there is a dire need to develop innovative methods to determine the diversity by molecular mean that would substantially beneficial for researchers and breeders $\left[{ }^{16}\right]$. As compared to rice, maize or tomatoes, the development in molecular genetics in wheat has been relatively slow, due to polyploidy difference, complexity and the size of its genome $\left[{ }^{17}\right]$, low level of polymorphism and high percentage of repetitive sequence $\left[{ }^{18}\right]$.

Molecular marker technology is an important tool of biotechnology because it's not influenced by environment, are abundant and don't require previous pedigree information, which can enhance the efficiency of molecular breeding practices $\left[{ }^{19}\right]$.A different kind of molecular markers are used to determine the genetic diversity including labeled probe primers AFLP and SSR $\left[{ }^{20}\right]$. These methods are based on polymerase chain reaction (PCR) with the use of RAPD $\left.{ }^{21,}{ }^{22}\right]$, simple sequence repeat (SSR or microsatellites) analysis $\left[{ }^{23,}{ }^{24}\right]$.Precision and excellence in the selection of germplasm are achieved by the expansion of molecular DNA markers $\left[{ }^{25}\right]$.

Genetic diversity analyses by molecular means played an important role in genomic structure composition, figure out important genes for specific traits, and finally preservedthe genetic materials for future use for plant breeding $\left[{ }^{26}\right]$.The evaluation of genetic diversity in diploid,tetraploid and hexaploid wheat is effectively measured by the RAPD technique $\left[{ }^{27}\right]$. Due to its simplicity, effectiveness and no necessity of sequence information $\left[{ }^{28,}{ }^{29}\right]$. RAPD have gained significance among many other DNA based techniques from genomic DNA utilizing random primers of arbitrary sequence $\left[{ }^{30}\right]$.The elite cultivars were found helpful for estimation of genetic distance between the actual routine sequences $\left[{ }^{31}\right]$ and establish the difference between genetic differences due to extensive breeding programs $\left[{ }^{32}\right]$.The morphological attributes can also be used to determine the genetic diversity, 
along with molecular markers is a direct genetic approach to figure out the desired gene (s) or gene product that have a positive effect on the crop plant. In short, RAPD markers express a large number of genes with greater accuracy to determine the genetic diversity $\left[{ }^{33}\right]$.

This study reveals the genetic relationship and population structure of different Pakistani wheat cultivarsfrom different geographical origin. The information about the genetic differences within and between different populations, which can be efficiently used by breeders for the production of genetically diverse wheat cultivars.

\section{MATERIALS AND METHODS}

\section{PLANT MATERIAL}

Seeds of fourteen wheat cultivars belonging to TriticumaestivumL.were collected from Department of Plant Breeding and Genetics, University of Agriculture, Faisalabad. The seeds were planted in pots during normal growing season and after germination 8-10 leaves were obtained from plants and frequently stored at $80^{\circ} \mathrm{C}$ for DNA isolation. The wheat cultivars used for experiment are listed in

Table 1).

Table 1 Wheat Cultivars and their ploidy level

\begin{tabular}{cccc}
\hline \multicolumn{1}{c}{ Cultivars } & Ploidy level & Cultivars & Ploidy level \\
\hline Aas-11 & Hexaploid & Minthar-03 & Hexaploid \\
AARI-11 & Hexaploid & Inqalab-91 & Hexaploid \\
SH-2002 & Hexaploid & FD-85 & Hexaploid \\
Barani-83 & Hexaploid & PBW-222 & Hexaploid \\
Koh e Noor-83 & Hexaploid & FD-83 & Hexaploid \\
Punjab-11 & Hexaploid & MH-97 & Hexaploid \\
Millat-11 & Hexaploid & Pak-81 & Hexaploid \\
\hline
\end{tabular}

\section{DNA ISOLATION}

DNA from these samples was extracted from leaf tissue by the following modified CTAB procedure $\left[{ }^{34}\right]$. PCR conditions were optimized according to the concentration of genomic DNA, $\mathrm{MgCl}_{2} 10 \mathrm{X}$ PCR buffer, primer, dNTPs, Taq DNA polymerase and annealing temperature as these factors influence the reproducibility of RAPD technique and the type of thermal cycler used. The RAPDPCR reaction was performed in 25 ul containing [10x Buffer $+\left(\mathrm{NH}_{4}\right)_{2} \mathrm{SO}_{4}$ is $2.5 \mathrm{ul}, \mathrm{d} 2 \mathrm{~h} 208.3 \mathrm{ul}$, Gelatin $(0.025 \%)$ is $2.5 \mathrm{ul}, \mathrm{MgCL}_{2}(50 \mathrm{mM}) 3.0 \mathrm{ul}$,

Table 2). Amplified products were electrophoresed on a $1.5 \%$ agarose gel using TBE buffer $0.5 \mathrm{x} .5 \mathrm{ul}$ of each PCR product and visualized using a gel documentation system.

\section{DATA ANALYSIS}

The RAPD bands were scored as 0 for their absence and 1 for their presence, generating a matrix. The genetic similarity was computed by UPGMA [ ${ }^{35}$ ]clustering (Unweighted Pair Group Methods of Arithmetic Average). The polymorphism information content (PIC) for each primer was calculated to estimate its allelic variation according to the formula
dNTPs (2.5mM each) is $4.0 \mathrm{ul}$, Primer (15ng/ul) $2.0 \mathrm{ul}$, Taq DNA polymerase (0.2U/ul) 0.2 and DNA template $(15 \mathrm{ng} / \mathrm{ul})$ is $2.5 \mathrm{ul}$ ]. Amplification was carried out by PCR thermal cycler (AG No. 533300839, Germany) in a reaction as follows: initial denaturation at $94{ }^{\circ} \mathrm{C}$ for $5 \mathrm{~min}$ followed by forty cycles of denaturation for $1 \mathrm{~min}$, annealing temperature $36{ }^{\circ} \mathrm{C}$ for $1 \mathrm{~min}$ and elongation time at $72{ }^{\circ} \mathrm{C}$ for $2 \mathrm{~min}$ and final extension at $72{ }^{\circ} \mathrm{C}$ for 10 min. The reaction was performed in a total volume of $25 \mu \mathrm{l}$. The RAPD primers and their sequence were presented in

$$
\mathrm{PIC}=1-\sum_{j=1}^{n} P_{i j}{ }^{2}
$$

Where $P \mathrm{ij}$ is the frequency of the $i$ th allele for marker $\mathrm{j}$ and the summation extends over $n$ alleles, calculated for each RAPD marker $\left[{ }^{36}\right]$. Data generated from RAPDanalysis were analyzed using Jaccard similarity coefficient $\left[{ }^{37}\right]$. These similarity coefficients were used to construct the dendrogram using the unweighted pair group method with arithmetic average (UPGMA) employing the SAHN (sequential, agglomerative, hierarchical, and nested clustering) from the NTSYS-pc (version 2.1) software $\left[{ }^{38}\right]$. The 
correlation and similarity matrix are determined by

using a Mantel test.

Table 2.Description of 14 wheat RAPD primers and their sequences.

\begin{tabular}{cccc}
\hline \multicolumn{1}{c}{ Primer code } & Primer sequence & Primer code & Primer sequence \\
\hline GL DecamerA-13 & 5'- TGCTCTGCCC -3' & GL Decamer K-01 & 5'- TCATCCGAGG -3' \\
GL DecamerA-14 & 5'- GGTGACGCAG -3' & GL Decamer K-03 & 5'- TCGTTCCGCA -3' \\
GL DecamerB-04 & 5'- GTCCACACGG -3' & GL Decamer K-12 & 5'- CCCAGCTGTG -3' \\
GL DecamerB-09 & 5'- GTAGACCCGT -3' & GL Decamer K-16 & 5'- CACAGGCGGA -3' \\
GL DecamerB-11 & 5'- CCTTGACGCA -3' & GL Decamer K-17 & 5'- GTGTCGCGAG -3' \\
GL DecamerB-13 & 5'- TTTGCCCGGA -3' & GL Decamer L-05 & 5'- GACTGCACAC -3' \\
GL DecamerB-17 & 5'- AGGGAACGAG -3' & GL Decamer L-11 & 5'- ACGCAGGCAC -3' \\
\hline
\end{tabular}

\section{RESULTS}

The dendrogram shows $92.5 \%$ genetic similarity among the wheat genotypes (Fig. 1). The dendrogram was cut at 0.50 similarity index value, which was averaged value for similarity. The consensus tree was divided into 4 groups and 3 separate groups. Millat-11, PBW-222 and FD-85 is standing alone and not making any cluster with other wheat line. Punjab- 11 showed as the parent line in this cluster. AARI-11 is making group with SH-2002 at similarity 0.50 . FD-83 and inqalab-91 is in the same group at similarity 0.72 and is making group with Minthar-03. Group IV has 2 cultivars like Koh e noor and barani-83 at similarity 0.68 .

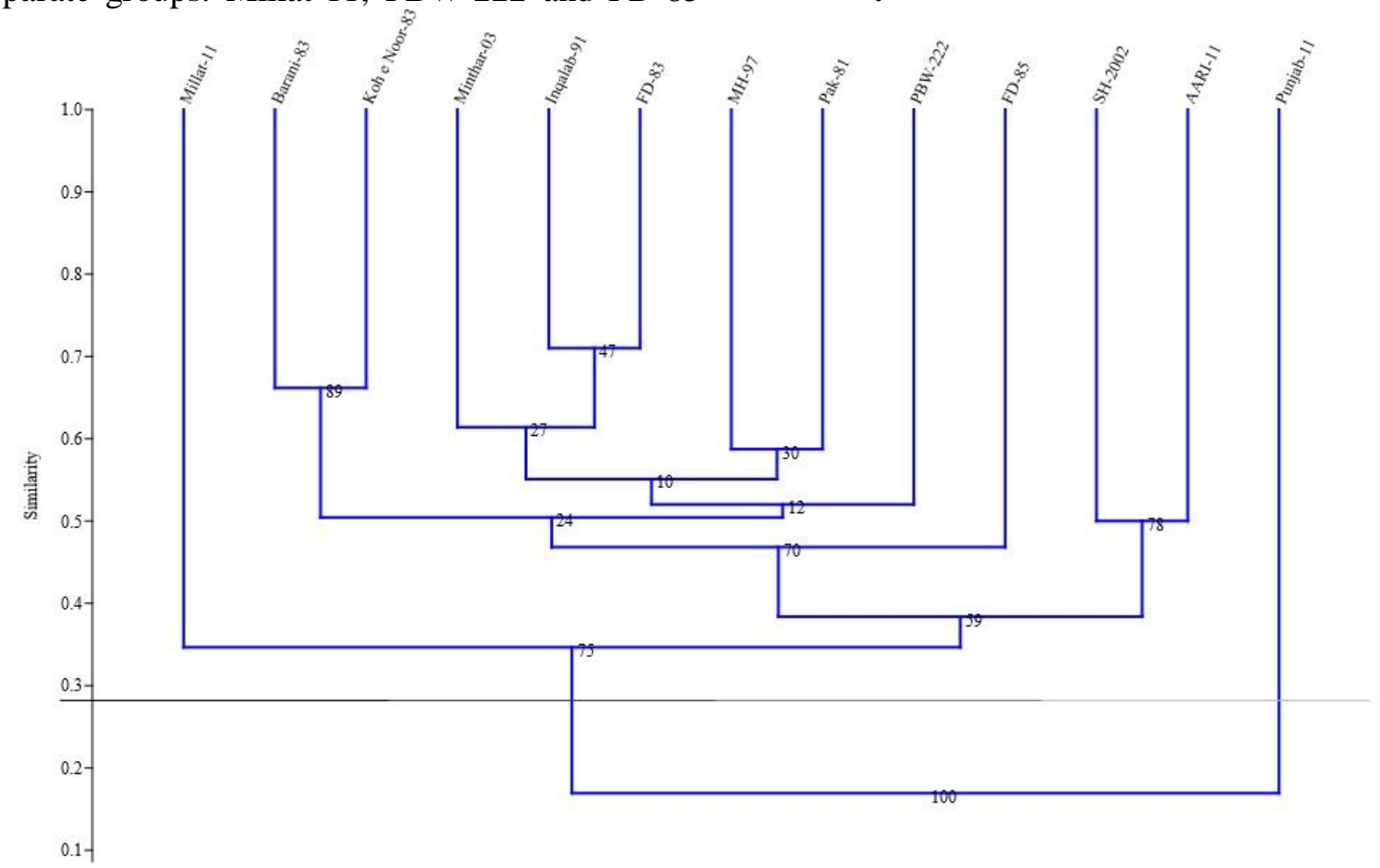

Figure 1 - Dendrogram produced by Jaccard's coefficient and the unweighted pair group method with arithmetic average (UPGMA) clustering method based on RAPD data in 14 wheat genotypes. 
Two dimensional biplot results were presented in Figure 2Fig. 2. PCoA1 have four cultivars that are more diverse as compared to other such as $\mathrm{SH}$ 2002, AARI-11, Millat-11, PBW-222 and Punjab11, while 2PCoA have Koh e Noor 83, Barani-83, FD 85 and Inqilab-91. All the four cultivars are away from the center, which means that these are diversefrom others. The eigenvalue and \% variance data on the basis of RAPD score data using (UPGMA) was presented ( figure 2 table 3 ). It represents that the cumulative Eigen value for six coordinates have 1.91 from all coordinates. The percentage variances or diversity among the wheat cultivars for first six coordinatesare $80 \%$ of the total.

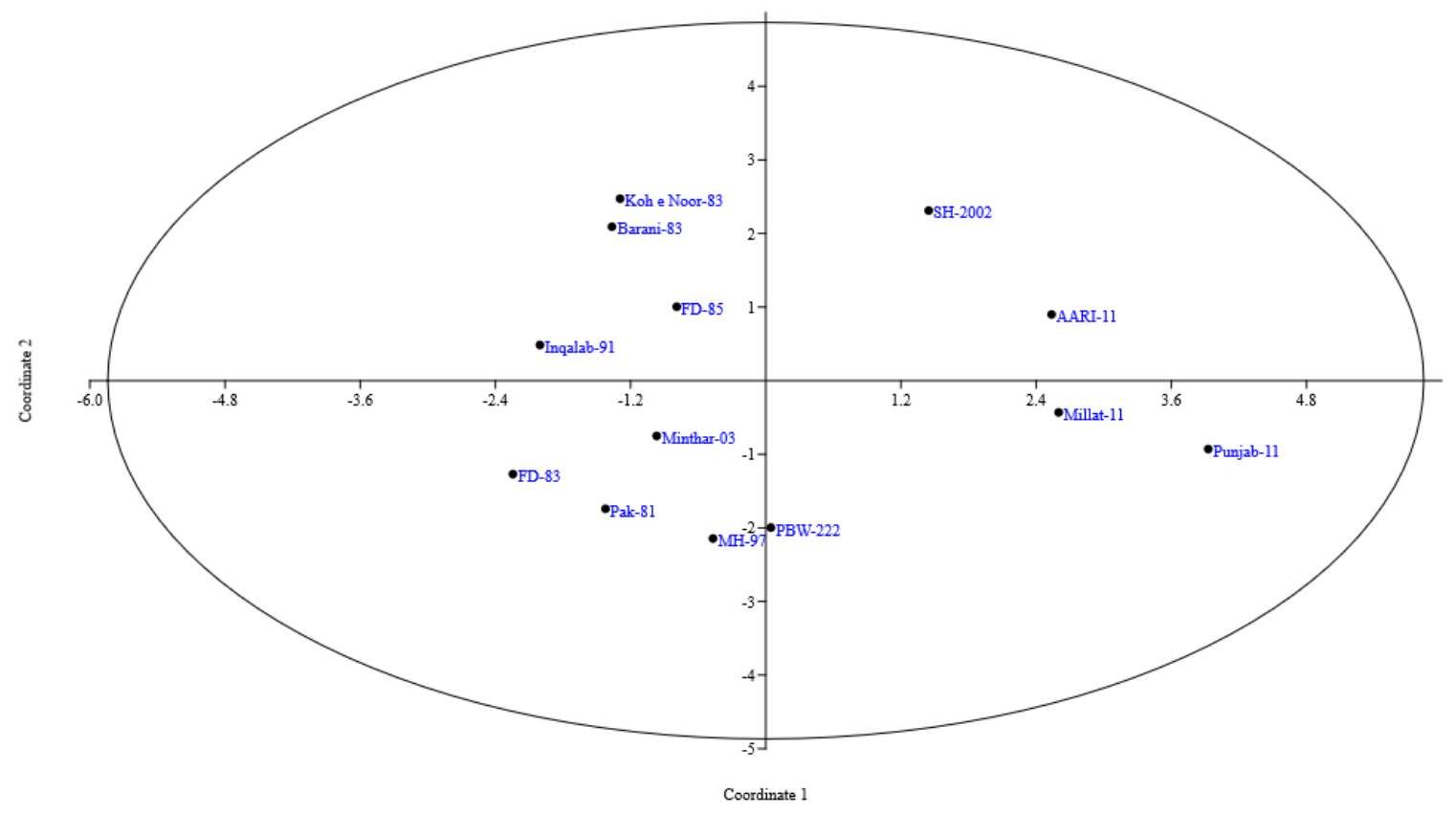

Figure 2 Two-dimensional plot based on Jaccard coefficient with the first two principal coordinates analysis on the basis of RAPD markers for 14 Wheat Varieties.

Table 3. Cumulative Eigenvalue and \% variance of all principle components analysis (PCoA) based on RAPD markers

\begin{tabular}{lrrrr}
\hline Coordinates & Eigenvalue & $\begin{array}{c}\text { Cumulative } \\
\text { Eigenvalue }\end{array}$ & Percent Variance & Cumulative \\
\hline 1 & 0.63 & 0.63 & 26.32 & 26.32 \\
2 & 0.37 & 1.00 & 15.36 & 41.67 \\
3 & 0.29 & 1.29 & 12.31 & 53.98 \\
4 & 0.25 & 1.54 & 10.61 & 64.59 \\
5 & 0.20 & 1.75 & 8.46 & 73.05 \\
6 & 0.17 & 1.91 & 6.94 & 80.00 \\
\hline
\end{tabular}


Table 4. Principal component coordinates (PCoA) analysis results for 14 Wheat cultivars produced by RAPD score data

\begin{tabular}{lccccc}
\hline & Coord 1 & Coord 2 & Coord 3 & Coord 4 & Coord 5 \\
\hline AARI-11 & 0.37 & 0.16 & 0.54 & -0.28 & -0.21 \\
SH-2002 & 0.21 & 0.40 & 0.27 & -0.15 & 0.19 \\
Barani-83 & -0.20 & 0.37 & 0.02 & 0.43 & 0.01 \\
Koh e Noor-83 & -0.19 & 0.43 & -0.04 & 0.41 & 0.07 \\
Punjab-11 & 0.57 & -0.16 & -0.30 & 0.04 & -0.01 \\
Millat-11 & 0.38 & -0.08 & -0.30 & 0.25 & -0.27 \\
Minthar-03 & -0.14 & -0.13 & -0.28 & 0.07 & -0.08 \\
Inqalab-91 & -0.29 & 0.08 & -0.21 & -0.35 & -0.47 \\
FD-85 & -0.12 & 0.18 & -0.34 & -0.56 & 0.47 \\
PBW-222 & 0.01 & -0.35 & 0.04 & 0.10 & 0.09 \\
FD-83 & -0.33 & -0.22 & 0.05 & -0.14 & -0.26 \\
MH-97 & -0.07 & -0.37 & 0.13 & 0.11 & 0.56 \\
Pak-81 & -0.21 & -0.30 & 0.44 & 0.06 & -0.10 \\
\hline
\end{tabular}

For better understanding the relationship among these cultivars were determined by the principal coordinate's analysis (PCoA). It was used to construct the data set to determine the similarities among the genotypes. The first six coordinates showed $80 \%$ cumulative variance of the total which means that RAPD primers showed diversity among the wheat cultivars. The First PCoA(26.31) which was followed by $15.35,12.30,10.61,8.46$ and 6.94 in second, third, fourth, five and six coordinates respectively. The principal coordinates for 14 wheat cultivars data was presented (
Table 4). The data regarding coordinates represent that PCoA have five cultivars named AARI-11, SH-2002, Punjab-11, Millat-11 and PBW-222, while the second coordinates have six cultivars named AARI-11, SH-2002, Barani-83, Koh e Noor 83, Inqilab-91 and FD-85. The maximum Euclidean distance $(0.57,0.38,0.37$, and 0.21$)$ was observed in Punjab-11, Millat-11, AARI-11 and SH-2002 in PCoA1 respectively. The maximum distance (0.43) was observed in Koh e Noor 83 in PCoA 2 which was followed by 0.40 (SH-2002), 0.36 (Barani-83), 0.15 (AARI-11) and least was 0.08 (Inqalab-91).

Table 5. Total Number of fragments and PIC value for each primer producing diversity among wheat cultivars

\begin{tabular}{lcc}
\hline Primers name & Total Fragments & PIC value \\
\hline GL DecamerA-13 & 38 & 0.85 \\
GL DecamerA-14 & 56 & 0.84 \\
GL DecamerB-04 & 69 & 0.87 \\
GL DecamerB-09 & 35 & 0.78 \\
GL DecamerB-11 & 49 & 0.82 \\
GL DecamerB-13 & 57 & 0.87 \\
GL DecamerB-17 & 57 & 0.82 \\
GL Decamer K-01 & 43 & 0.87 \\
GL Decamer K-03 & 52 & 0.88 \\
GL Decamer K-12 & 49 & 0.88 \\
GL Decamer K-16 & 39 & 0.82
\end{tabular}


The polymorphic information content (PIC), measured as the percentage of polymorphic fragments for all primer pairs were presented in

Table 5) and varied ranged from (79- $87 \%$ ). The maximum PIC (polymorphic information contents) was $87 \%$ with (GL Decamer B-13) and producing 38 fragments in all 14 wheat cultivars while a minimum PIC value (0.79) was observed in primer (GL Decamer K-17) and producing 39 fragments bands. The average value of each primer is 48.52 among all the primers used in this experiment and producing $84 \%$ PIC as an average for each primer. The ability for producing diversity for each RAPD primer varies significantly for all range $38-69$ loci. The Jaccard's similarity coefficient among 14 wheat cultivars based on RAPD data was presented in Erro! Fonte de referência não encontrada.).

Table 6. Jaccard's similarity coefficient among 14 wheat cultivars based on RAPD data

\begin{tabular}{|c|c|c|c|c|c|c|c|c|c|c|c|c|c|}
\hline & $\begin{array}{c}\text { AARI } \\
-11\end{array}$ & $\begin{array}{l}\text { SH- } \\
2002\end{array}$ & $\begin{array}{r}\text { Bara } \\
\text { ni- } 83\end{array}$ & $\begin{array}{c}\text { Koh } \\
\text { e } \\
\text { Noor } \\
-83\end{array}$ & $\begin{array}{l}\text { Punja } \\
\text { b-11 }\end{array}$ & $\begin{array}{l}\text { Milla } \\
\mathrm{t}-11\end{array}$ & $\begin{array}{l}\text { Mint } \\
\text { har- } \\
03\end{array}$ & $\begin{array}{c}\text { Inqal } \\
\text { ab- } \\
91\end{array}$ & $\begin{array}{c}\text { FD- } \\
85\end{array}$ & $\begin{array}{l}\text { PBW } \\
-222\end{array}$ & $\begin{array}{c}\text { FD- } \\
83\end{array}$ & $\begin{array}{l}\text { MH- } \\
97\end{array}$ & $\begin{array}{c}\text { Pak- } \\
81\end{array}$ \\
\hline AARI-11 & 1.00 & & & & & & & & & & & & \\
\hline SH-2002 & 0.50 & 1.00 & & & & & & & & & & & \\
\hline $\begin{array}{l}\text { Barani-83 } \\
\text { Koh e }\end{array}$ & 0.36 & 0.48 & 1.00 & & & & & & & & & & \\
\hline $\begin{array}{l}\text { Noor-83 } \\
\text { Punjab- }\end{array}$ & 0.36 & 0.49 & 0.66 & 1.00 & & & & & & & & & \\
\hline 11 & 0.19 & 0.14 & 0.15 & 0.13 & 1.00 & & & & & & & & \\
\hline $\begin{array}{l}\text { Millat-11 } \\
\text { Minthar- }\end{array}$ & 0.30 & 0.35 & 0.34 & 0.38 & 0.29 & 1.00 & & & & & & & \\
\hline $\begin{array}{l}03 \\
\text { Inqalab- }\end{array}$ & 0.31 & 0.41 & 0.54 & 0.53 & 0.21 & 0.42 & 1.00 & & & & & & \\
\hline 91 & 0.33 & 0.41 & 0.55 & 0.54 & 0.14 & 0.33 & 0.58 & 1.00 & & & & & \\
\hline FD-85 & 0.29 & 0.41 & 0.46 & 0.49 & 0.11 & 0.28 & 0.50 & 0.54 & 1.00 & & & & \\
\hline PBW-222 & 0.32 & 0.38 & 0.43 & 0.44 & 0.19 & 0.39 & 0.49 & 0.44 & 0.41 & 1.00 & & & \\
\hline FD-83 & 0.40 & 0.45 & 0.58 & 0.55 & 0.18 & 0.40 & 0.65 & 0.71 & 0.53 & 0.61 & 1.00 & & \\
\hline MH-97 & 0.31 & 0.37 & 0.46 & 0.43 & 0.18 & 0.31 & 0.52 & 0.43 & 0.42 & 0.50 & 0.59 & 1.00 & \\
\hline Pak-81 & 0.44 & 0.39 & 0.51 & 0.50 & 0.12 & 0.33 & 0.55 & 0.52 & 0.41 & 0.56 & 0.69 & 0.59 & 1.00 \\
\hline
\end{tabular}

\section{DISCUSSION}

Genetic diversity analysis is important to interpret the genetic relationship, including parentage and their management of genotypes and hence used for breeding improvement $\left.{ }^{39}\right]$. Molecular characterization is more valuable than morphological because in molecular data, a large number of data set or alleles are present within the same species, while morphological traits might be affected by environment $\left[{ }^{40,41}\right]$.As a result RAPD primers are used to evaluate genetic diversity among the 14 hexaploid wheat cultivars. The polymorphic information contents (PIC) for all primers combinations were $84 \%$, which is very high and predicted that the diversity is present among the wheat cultivars. These results are lined with $\left[{ }^{42,43,44,45}\right]$ reported that $80.52 \%, 61 \%, 62.5$ $\%, 71.10 \%$ polymorphism intensity was observed respectively. Similar results were obtained 
by $\left.{ }^{46,47,48,49,50}\right]$ reported that RAPD primers showed $83 \%, 89 \%, 79.8 \%, 81 \%$ and $92.5 \%$ diversity respectively for different cultivars.

The average number of amplified fragments for each primer is 48.52 greater that $\left[{ }^{51}\right]$ who observed 22.32 fragments bands per primer. Our results are more similar with $\left[{ }^{45}\right]$ who discovered 46.37 fragments while $\left[{ }^{52}\right]$ and $\left[{ }^{46}\right]$ observed 57 bands per primers from wheat cultivars. In another study $\left[{ }^{49}\right]$ reported that 53 fragments per primers were reported in the evaluation of common wheat cultivars at different locations. Though, molecular characterization considerably contributes towards phenotypic variation, but cannot be accurately phenotype $\left[{ }^{42}\right]$. So genetic diversity is best studied at the level of arrangement of nucleotide bases in genomic DNA, which is the primary source of all biological information $\left[{ }^{53}\right]$. At this stage, even identical seeming accessions could display vast differences, if only we could use appropriate DNA profiling techniques. Besides, the availability of a number of molecular markers, RAPD is one such method $\left[{ }^{54,55}\right]$ of discovering polymorphism that can be used to elicit information on genetic variations between individuals of a population, among lines or germplasm or any breeding material.

\section{CONCLUSION}

The present study was conducted to determine with the aimed to determine the genetic diversity among the wheat hexaploid grown in Pakistan using RAPD molecular markers. Our results revealed that the wheat cultivars $\mathrm{SH}-2002$ and AARI-11 are the more diverse genotypes from the other while Millat-11, Punjab-11 and PBW-222 are closely related to SH-2002 and AARI-11 present in the PCoA. From cluster data it was revealed that Millat-11, Punjab-11 and PBW-222 are the more diverse genotypes and standing alone in the cluster as compared to others. SH-2002 and AARI-11 is making group with each other in one group while FD-83, Inqalab-91 and Minthar-03 is in the second group. RAPD markers also showed diversity among the wheat cultivars by PIC values range (78-87\%). So, finally we can conclude that RAPD markers are a good technique by which we can determine the genetic diversity among and within the wheat cultivars.

\section{ACKNOWLEDGMENT}

The author wishes to thank the Centre of Agricultural Biochemistry and Biotechnology (CABB), University of Agriculture Faisalabad and Deanship of Scientific Research at King Saud University Riyadh, Saudi Arabia on completion of this article.

\section{REFERENCES}

1-Anonymous. Pakistan Economic Survey 2004-05. Govt. of Pakistan, Finance Division, Economic Advisor's Wing, Islamabad 2005.

2-FAO. Production and protection series 2015 http://www.fao.org/worldfoodsituation/csdb/en/?fb_=

3-Liu ZQ, Pei Y, Pu ZJ. Relationship between hybrid performance and genetic diversity based on RAPD markers in wheat, Triticumaestivum L. Plant breeding. 1999; 118(2):119-23.

4-Vermeulen SJ, Campbell BM, Ingram JS. Climate change and food systems. Annual Review of Environment and Resources. 2012; 37(1):195.

5-Wheeler T. Agriculture: Wheat crops feel the heat. Nature Climate Change. 2012; 2 (3):152-3.

6-Summers R, Brown J. Constraints on breeding for disease resistance in commercially competitive wheat cultivars. Plant Pathology. 2013; 62(S1):115-21.

7-Shewry PR. Improving the protein content and composition of cereal grain. Journal of Cereal Science. 2007; 46(3):239-50.

8-Shewry PR. Wheat. Journal of experimental botany. 2009; 60 (6):1537-53.

9-Kundu S, Nagarajan S, Karnal D. Distinguishing Characters of Indian Wheat Varities: Directorate of Wheat Research; 1998.

10- Perrino P, Porceddu E, Srivastava J, Damania A, editors. Wheat genetic resources in Ethiopia and the Mediterranean region. Wheat genetic resources: meeting diverse needs; 1990: John Wiley \& Sons.

11- Pejic I, Ajmone-Marsan P, Morgante M, Kozumplick V, Castiglioni P, Taramino G, et al. Comparative analysis of genetic similarity among maize inbred lines detected by RFLPs, RAPDs, SSRs, and AFLPs. Theoretical and Applied genetics. 1998; 97:1248-55.

12- Fufa H, Baenziger P, Beecher B, Dweikat I, Graybosch R, Eskridge K. Comparison of phenotypic and molecular marker-based classifications of hard red winter wheat cultivars. Euphytica. 2005; 145:13346.

13- Marić S, Bolarić S, Martinčić J, Pejić I, Kozumplik V. Genetic diversity of hexaploid wheat cultivars estimated by RAPD markers, morphological traits and coefficients of parentage. Plant Breeding. 2004; 123(4):366-9. 
14- Kim H, Ward R. Patterns of RFLP-based genetic diversity in germplasm pools of common wheat with different geographical or breeding program origins. Euphytica. 2000; 115:197-208.

15- Migdadi H, Tell A, Masoud S. Genetic diversity in some Aegilops species in Jordan as revealed by RAPDs. Plant Genetic Resources Newsletter. 2004.

16- Kazan K, Manners JM, Cameron DF. Inheritance of random amplified polymorphic DNA markers in an interspecific cross in the genus Stylosanthes. Genome. 1993;36(1):50-6.

17- Gollin D, Smale M, Skovmand B. Searching an ex situ collection of wheat genetic resources. American Journal of Agricultural Economics. 2000; 82:812-27.

18- Hoisington D, Bohorova N, Fennell N, Khairallah M, Pellegrineschi A, Ribout J. Plant production and protection series. 2002.

19- Motawei M, Al-Doss A, Moustafa K. Genetic diversity among selected wheat lines differing in heat tolerance using molecular markers. Journal of Food Agriculture and Environment. 2007; 5:180.

20- Maurer Jr CR, Fitzpatrick JM, Wang MY, Galloway RL, Maciunas RJ, Allen GS. Registration of head volume images using implantable fiducial markers. Medical Imaging, IEEE Transactions on. 1997; 16:447-62.

21- Jensen HW, Buhler J. A rapid hierarchical rendering technique for translucent materials. ACM Transactions on Graphics (TOG). 2002; 21:576-81.

22- Gaitan A, Valderrama AM, Saldarriaga G, Velez P, Bustillo A. Genetic variability of Beauveriabassiana associated with the coffee berry borer Hypothenemus hampei and other insects. Mycological Research. 2002; 106:1307-14.

23- Kretzer AM, Molina R, Spatafora JW. Microsatellite markers for the ectomycorrhizal basidiomycete Rhizopogonvinicolor. Molecular Ecology. 2000;9:1190-1.

24- Enkerli J, Koelliker R, Keller S, Widmer F. Isolation and characterization of microsatellite markers from the entomopathogenic fungus Metarhiziumanisopliae. Molecular Ecology Notes. 2005; 5:384-6.

25- Tar'an B, Zhang C, Warkentin T, Tullu A, Vandenberg A. Genetic diversity among cultivars and wild species accessions of pea (Pisumsativum L.) based on molecular markers, and morphological and physiological characters. Genome. 2005; 48:257-72.

26- Khan MK, Pandey A, Thomas G, Akkaya MS, Kayis SA, Ozsensoy Y, et al. Genetic diversity and population structure of wheat in India and Turkey. AoB Plants. 2015; 7: plv083.

27- $\quad$ Myburg A, Botha A, Wingfield B, Wilding W. Identification and genetic distance analysis of wheat cultivars using RAPD fingerprinting. Cereal research communications. 1997:875-82.
28- Gepts P. The use of molecular and biochemical markers in crop evolution studies. Evolutionary biology: Springer; 1993. p. 51-94.

29- Karp A. Molecular tools in plant genetic resources conservation: a guide to the technologies: Bioversity International; 1997.

30- Milla S, Levin J, Lewis R, Rufty R. RAPD and SCAR Markers Linked to an Introgressed Gene Conditioning Resistance to DB Adam. in Tobacco. Crop science. 2005; 45:2346-54.

31- Ali Y, Atta BM, Akhter J, Monneveux P, Lateef Z. Genetic variability, association and diversity studies in wheat (Triticumaestivum L.) germplasm. Pak J Bot. 2008; 40 (5):2087-97.

32- Fu Y-B, Somers DJ. Genome-wide reduction of genetic diversity in wheat breeding. Crop Science. 2009; 49:161-8.

33- Stachel M, Lelley T, Grausgruber H, Vollmann J. Application of microsatellites in wheat (Triticumaestivum L.) for studying genetic differentiation caused by selection for adaptation and use. Theoretical and Applied Genetics. 2000; 100:242-8.

34- Khan MK, Pandey A, Thomas G, Akkaya MS, Kayis SA, Ozsensoy Y, et al. Genetic diversity and population structure of wheat in India and Turkey. AoB Plants. 2015; 7:plv083.

35- Sneath PH, Sokal RR. Numerical taxonomy. The principles and practice of numerical classification 1973.

36- Anderson JA, Churchill G, Autrique J, Tanksley S, Sorrells M. Optimizing parental selection for genetic linkage maps. Genome. 1993; 36:181-6

37- Jaccard P. Nouvellesrecherches sur la distribution florale1908.

38- Rolph NTSYS-pc. Numerical taxonomy and multivariate analysis system, version 2.2. Setauket, NY, USA: Exeter Publishing. 2000.

39- Al-Doss AA, Elshafei AA, Moustafa KA, Saleh M, Barakat MN. Comparative analysis of diversity based on morphoagronomic traits and molecular markers in durum wheat under heat stress. African Journal of Biotechnology. 2013; 10:3671-81.

40- Chinnusamy V, Zhu J, Zhu J-K. Cold stress regulation of gene expression in plants. Trends in plant science. 2007; 12:444-51.

41- Shinozaki K, Yamaguchi-Shinozaki K. Gene networks involved in drought stress response and tolerance. Journal of experimental botany. 2007; 58:221-7.

42- $\quad$ Ahmed MF, Iqbal M, Masood MS, Rabbani MA, Munir M. Assessment of genetic diversity among Pakistani wheat (Triticumaestivum L.) advanced breeding lines using RAPD and SDSPAGE. Electronic Journal of Biotechnology. 2010; 13(3):1-2.

43- Gerashchenkov G, Gorbunova V, Zarianova L, Rozhnova N, Bakhitov V. [RAPD-PCR analysis of 
the variability of spring common wheat cultivar genomes and their androclinal double haploid form]. Genetika. 2000; 36(8):1081-7.

44- Abd-El-Haleem S, Reham M, Mohamed S. Genetic analysis and RAPD polymorphism in some durum wheat genotypes. Global J Biotech Biochem. 2009; 4:1-9.

45- Tahir MS. Reaction of different wheat (Triticumaestivum L.) genotypes in response to salt stress and genetic mapping of QTL for salt tolerance using AFLP markers: Inst. fürPflanzenbau und Pflanzenzüchtung; 2002.

46- Naghavi MR, Mardi M, Ramshini HA, Fazelinasab B. Comparative analyses of the genetic diversity among bread wheat genotypes based on RAPD and SSR markers. Iranian Journal of Biotechnology. 2004;2:195-202.

47- Iqbal A, Khan A, Khan I, Awan F, Ahmad A, Khan A. Study of genetic divergence among wheat genotypes through random amplified polymorphic DNA. Genet Mol Res. 2007;6476-81.

48- Rashid H, Shafi S, Booy R, El Bashir H, Ali K, Zambon $\mathrm{M}$, et al. Influenza and respiratory syncytial virus infections in British Hajj pilgrims. Emerg Health Threats J. 2008.

49- $\quad$ Siddiqui MF, Iqbal S, Erum S, Naz N, Khan S. DNA landmarks for genetic relatedness and diversity assessment in Pakistani wheat genotypes using RAPD markers. Pak J Bot. 2010; 42:1013-20.

50- $\quad$ Farrakh S, Ahmad I, Mirza JI, Hameed S, Kazi M, Ashraf M. RAPD analysis of stripe rust resistant synthetic hexaploid of wheat. Int $\mathbf{J}$ ApplSci Tech. 2011.

51- Cenkci S, Yildiz M, Konuk M, Eren Y. RAPD analyses of some wild Triticum L. and Aegilops L. species and wheat cultivars in Turkey. ActaBiolCracovien Bot. 2008;50:35-42.

52- Mahmood T, Siddiqua A, Rasheed A, Nazar N. Evaluation of genetic diversity in different Pakistani wheat land races. Pak J Bot. 2011; 43(2):1233-9.

53- William H, Trethowan R, Crosby-Galvan E. Wheat breeding assisted by markers: CIMMYT's experience. Euphytica. 2007; 157:307-19.

54- Williams JG, Kubelik AR, Livak KJ, Rafalski JA, Tingey SV. DNA polymorphisms amplified by arbitrary primers are useful as genetic markers. Nucleic acids research. 1990; 18:6531-5.

55- Welsh, John, and Michael McClelland. "Fingerprinting Genomes Using PCR with Arbitrary Primers." Nucleic Acids Research.1990; 24: 72137218.

56- $\quad$ Ahmed MF, Iqbal M, Masood MS, Rabbani MA and Munir M. Assessment of genetic diversity among Pakistani wheat (Triticum aestivum L.) advanced breeding lines using RAPD and SDS-PAGE. Electronic J Biotech. 2010; 13: 3. 1-2. 